\title{
Dominique Brancher, Virgile en bas-de-chausse: Montaigne et la tradition de l'obscénité latine
}

\section{Filippo Fassina}

\section{OpenEdition}

\section{Journals}

\section{Edizione digitale}

URL: http://journals.openedition.org/studifrancesi/6590

DOI: 10.4000/studifrancesi.6590

ISSN: 2427-5856

\section{Editore}

Rosenberg \& Sellier

\section{Edizione cartacea}

Data di pubblicazione: 1 septembre 2010

Paginazione: 351

ISSN: 0039-2944

\section{Notizia bibliografica digitale}

Filippo Fassina, «Dominique Brancher, Virgile en bas-de-chausse: Montaigne et la tradition de l'obscénité latine», Studi Francesi [Online], 161 (LIV | II) | 2010, online dal 30 novembre 2015, consultato il 11 janvier 2021. URL: http://journals.openedition.org/studifrancesi/6590 ; DOI: https://doi.org/10.4000/ studifrancesi.6590

Questo documento è stato generato automaticamente il 11 janvier 2021.

\section{(c) $($ ) $(9)$}

Studi Francesi è distribuita con Licenza Creative Commons Attribuzione - Non commerciale - Non opere derivate 4.0 Internazionale. 


\title{
Dominique Brancher, Virgile en bas- de-chausse: Montaigne et la tradition de l'obscénité latine
}

\author{
Filippo Fassina
}

\section{NOTIZIA}

DOMINIQUE BRANCHER, Virgile en bas-de-chausse: Montaigne et la tradition de l'obscénité latine, «Bibliothèque d'Humanisme et Renaissance», LXX, 1 (2008), pp. 95-122.

1 Il presente studio è dedicato all'analisi del capitolo degli Essais di Montaigne intitolato «Sur des vers de Vergile», in cui viene commentato il passo virgiliano sull'amplesso fra Venere e Vulcano. L'A., in primo luogo, traccia una breve storia della posizione che occupano le espressioni di oscenità (definite kakemphaton) all'interno della retorica a partire da Quintiliano e fino al Rinascimento. Successivamente, vengono illustrate le opere di due grandi lettori di Virgilio dell'antichità: Aulo Gellio e Ausonio. Entrambi, attraverso le loro opere (rispettivamente le Noctes Atticae e il Cento Nuptialis), rivelano una vera e propria tradizione ermeneutica sull'oscenità che Montaigne ha certamente tenuto presente nella concezione di questo capitolo. Infine, si passa all'analisi del testo di Montaigne, sottolineandone gli aspetti legati alla pudeur nella descrizione dell'erotismo virgiliano, pudeur ereditata proprio dai due mediatori antichi. E proprio da questa pudeur deriva il fascino del capitolo degli Essais, che, pur mantenendo una bienséance di fondo, riesce a colpire il lettore grazie ad allusioni erotiche di grande efficacia retorica. 